
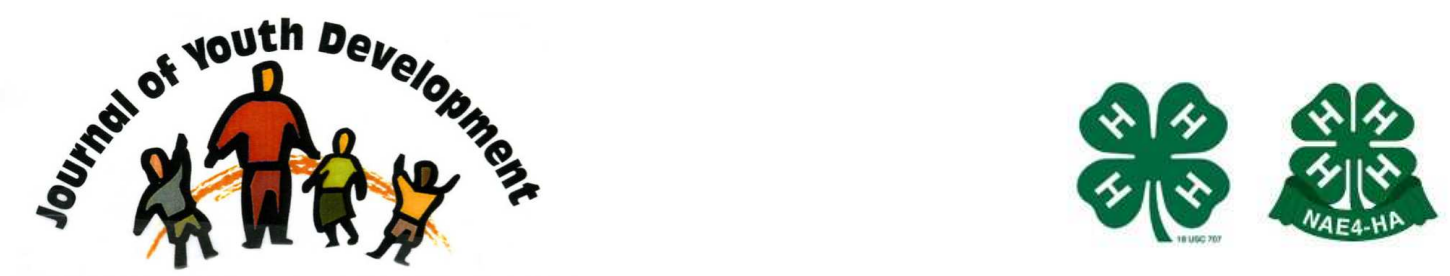

Bridging Research \& Practice

\title{
Great Teaching: Eight Strategies to Immediately Engage Your Audience
}

\author{
Brian Raison \\ Miami County Extension Office \\ The Ohio State University \\ Troy, $\mathrm{OH}$ \\ raison.1@osu.edu
}




\title{
JOURNAL OF YOUTH DEVELOPMENT \\ bridging research and practice

\section{Great Teaching: Eight Strategies to Immediately Engage Your Audience}

\author{
Brian Raison \\ The Ohio State University
}

\begin{abstract}
Have you ever been bored by a speaker before he finished his first sentence? What about when you step up to the front of a room to speak. Do you know exactly what your first words will be? Whether welcoming new students to the first class of a semester, making a presentation at a $4-\mathrm{H}$ event or speaking at a conference, your introductory statement can make or break you. In fact, your first two or three words can determine a successful launch or leave you stalled-out. This paper describes eight strategies that both novice and seasoned speakers may use to successfully launch presentations.
\end{abstract}

\section{Introduction}

Do you frequently find yourself stuck when trying to write the opening line for a speech? When you step up to the front of a group to speak, do you KNOW FOR CERTAIN what your FIRST WORDS will be... or do you take the casual approach, unconcerned that those first few words will make a difference?

Well, a casual opening may work. It's nice to ask, "How's everyone doing today?" But in truth, you probably do not want to hear the real answers to that question. You will have more impact and gain more credibility if you start with an immediate, meaningful connecting introduction (Gross Davis, 1993). By opening with impact, you can truly create a positive first impression (Carnegie, 2010). Regardless of whether your audience is made up of students or adults, you need to open with an attention-getting start. Here are some specific examples that really work:

\section{Startling Statistic/Surprise/Unexpected Fact}

Use a surprising fact related to your speech. Then ask a follow-up question that relates back. For example: "Every year, 1.5 million people file bankruptcy. That's 4,109 per day. How can you avoid a future like that?" 
Here's another: "Each fall, over 1.9 million high school seniors head off to college. But according to the ACT Board, $26 \%$ will not return for their sophomore year. That's one out of four! Are teachers and parents in YOUR community aware of this fact?"

Or perhaps try this: "In a tenth of a second, you can get over eight million results from a Google search on 'peer pressure.' But tell me this: How do you know what web site to trust?"

\section{Quotation}

Quoting a current-day expert or historical figure (real or fictional) can set the stage for your speech. After the quote, follow up with a question: "What do you think she meant by saying this?" Or ask, "Is this still relevant today?"

Use great caution if quoting a controversial person or saying. Remember what your grandmother taught you: "Never talk about religion or politics or the opposite sex in polite company."

Here's a humorous idiom on time management that you might try: Mark Twain once said, "Never put off till tomorrow what you can do the day after tomorrow" (St Peter, 2010). Another more poignant message from this American humorist might also launch a talk: "Travel is fatal to prejudice, bigotry and narrow-mindedness" (Twain, 1869).

\section{Thinking Analogy}

Get your audience to use their brain immediately. Use the word "imagine." It's engaging. For example: "Imagine that you invented the axle-not the wheel-but that ingenious thing that holds two wheels together and allows them to do the work." Then pose a question: "Who's the first person you would tell?" Or, "How would you let people know about your new invention?" Varying the question can lead your audience to the topic discussion you're about to launch.

Here's another: "I won't ask you to raise your hands! But here's a question: How many of you know the feeling you get when you see the State Highway Patrol's flashing lights in your rearview mirror? Could that be the same feeling some students get when called upon in class?"

\section{Rhetorical or Challenging Question}

Begin by stating, "You don't have to raise your hands... but how many of you have... (told a lie, broken the law, etc.)?" This quickly relieves the audience of the worry they'll have to share their responses.

"Have you ever taken 10 minutes to write your $100^{\text {th }}$ birthday party speech? Regardless of how old you are today, what one thing do you want to brag about when you're 100?" (Important: Give them a moment to think about it. Perhaps you could share one of your answers during the pause. e.g., "I'd like to brag about my best-selling novel... or my 50 years of community service.")

\section{Quiz / Survey Opening}

Something like this is more involved; but it can work. Before you try it though, practice on a friend or small group. It's more difficult than it may seem.

"Who remembers the Jetsons - that futuristic space family? What was the dad's name? [Pause. Repeat answer from participant for all to hear.] And his wife? [Pause. Repeat answer.] How 
about their daughter? Okay. Now, his boy ? And finally the dog was called

? You can probably sing the song as well. Okay. Now name five of the nine justices of the United States Supreme Court. [Pause.] Don't feel bad. I can't do it either. My point is, sometimes very important things that affect our lives are not in the forefront of our minds. So let's talk about (the environment... teen sex... bullying... alternative energy) and try to determine what we DO need to know or learn to make a positive impact."

\section{Personal Story}

Tell a short story... NOT a joke or someone else's story. Keep it brief and relevant to the topic. Unrelated stories, though humorous, rarely help to engage your audience.

For example, if your topic is social justice, begin with a personal experience that you have encountered. "In 1995, shortly after a failed coup and subsequent U.N. peacekeeping invasion, I undertook my first journey to the Republic of Haiti."

Or, the social justice topic could begin with a story more common to many people: "While leaving the downtown stadium after a ball game last week, a homeless person asked me for money. Has this ever happened to you?"

\section{Note the Occasion}

"I'm really excited to get to speak today at this conference. The fact you all are here attests to the importance of the topic. I hope I can provide some really good information you'll find valuable."

This also works as an introduction to a new class. Initiate your students with the central thesis that they'll be studying. Then challenge them with a great question related to the central theme? For example:

"In 1902, A.B. Graham started the first boys and girls clubs that later became 4-H. In the 1930's he advocated for urban and racially integrated clubs. This was an amazingly bold stance to take at the time. His actions set the stage for inclusion of all. Who was this man and why is his work so significant today?"

\section{Bring a prop}

You can catch an audience's attention quickly with a funny (or serious) display. An easy display to accumulate includes a record album (33 rpm), an 8-track (if you can find one at Goodwill), a cassette tape, a music $C D$, and an mp3 player (or smart phone). These vividly show the remarkable change in music delivery technology over a relatively short period of time. Then introduce your talk: "Ladies and gentlemen, Elvis has entered the digital age. Have you?"

\section{During Your Speech}

Your opening sentence sets the stage (UNC, 2012); but don't forget that you must work to keep your audience engaged throughout the talk or lecture (Mintz, nd). Here are some quick inclusions that good speakers use during a talk.

Chat with two or three students before class. Jot down a question or conversation from these pre-speech discussions and bring them up during your talk. Again, your consultation with audience members provides a connection and builds credibility. 
If you're at a conference with multiple speakers, paraphrase a previous speaker. Take some notes while you're waiting to speak. Then, at an appropriate point in your talk, mention it. This gives you credibility and builds rapport.

Engage the audience with questions during your talk. This is nothing new; but try it with a new twist. Set the audience up for the question. Try something like this: "In a minute, I'm going to ask you a specific question about this topic. When I do, I don't want you to answer immediately. Take a moment. Engage your thought processes, and then respond." Another simple question that might be engaging could ask, "How would affect your grandchildren's lives in the future?"

You may also ask someone in the audience to share an example of something you've just stated.

\section{Summary}

Does it really matter if you capture your audience with the first few words? Do you have to include them? Or is engaging them enough? Does that really set the tone for your success or failure? Here's an exercise that may help you think about it. Read the italicized sentence below and then pause for a moment (yes, quit reading) to let it sink in:

\section{Think about that little voice inside your head. [Now quit reading for a moment and think about the voice.]}

Okay. You probably had one of two standard reactions. The first might have been a little voice saying, "Okay, I'm pausing," or "Okay, I'm thinking about it," while you mentally drummed your fingers on your desktop for two or three seconds. The second possibility may have said, "Little voice? What little voice?" in a rather indignant tone. Either way, the italicized sentence got your attention.

Think about that italicized sentence as your opening statement. Whatever it is, you first words will set off a flurry of little voices in heads across the entire room. So ask yourself, do you want the voices to smile and say, "Hey this sounds interesting..." or do you mind if the little voices quietly whisper, "I wonder if I can FaceBook and text for the next hour without being noticed."

\section{References}

Carnegie, D. (2010). Presenting with Impact. Dale Carnegie Training, Presentation Effectiveness. Retrieved May 23, 2012 from: http://www.dalecarnegie.com/assets/1/1/PE PresentingwithImpact.pdf

Gross Davis, B. (1993). Tools for Teaching. Jossey-Bass Publishers: San Francisco. Excerpt retrieved May 24, 2012 from: http://teaching.berkeley.edu/bgd/delivering.html

Mintz, S. (nd). The Do's and Don'ts of Effective Lectures. The Graduate School of Arts \& Sciences Teaching Center at Columbia University. Retrieved May 24, 2012 from: http://www.columbia.edu/cu/tat/pdfs/lectures.pdf 
St. Peter, A. (2010). The Greatest Quotations of All-Time. Xlibris, Corp., pg. 512.

Twain, M. (1869). The innocents abroad [by] Mark Twain. London: Collins Clear-type Press.

UNC. (2012). Introductions. The Writing Center at the University of North Carolina at Chapel Hill. Retrieved May 24, 2012 from: http://writingcenter.unc.edu/resources/handoutsdemos/writing-the-paper/introductions

(C) Copyright of Journal of Youth Development Bridging Research and Practice. Content may not be copied or emailed to multiple sites or posted to a listserv without copyright holder's express written permission. However, users may print, download or email articles for individual use. 